\author{
Wanda Skoczylas* \\ Andrzej Niemiec**
}

\title{
PRZEDSIĘBIORSTWA SPOLECZNIE ODPOWIEDZIALNE W ŚWIETLE BADAŃ NAD POMIAREM DOKONAŃ
}

\section{WPROWADZENIE}

Przedsiębiorstwa w Polsce, ale też międzynarodowe korporacje mają świadomość rosnącej odpowiedzialności nie tylko wobec właścicieli, ale też wobec otoczenia biznesowego czy lokalnych społeczności. Ścieżce myślenia opartej na prawach rynku coraz częściej towarzyszy druga, oparta na etyce. Takie podejście do realizacji celów interesariuszy w większości wypadków jest źródłem przewagi konkurencyjnej przedsiębiorstw oraz umocnienia pozycji marki na rynku. Skuteczne wdrażanie strategii zrównoważonego rozwoju wymaga jej przełożenia na cele i mierniki. Przeprowadzone badania ankietowe dotyczące diagnozy pomiaru dokonań w przedsiębiorstwach polskich wykazały, że wiele z nich, oprócz tradycyjnie wyodrębnianych płaszczyzn oceny, mierzy cele w dwóch dodatkowych płaszczyznach: ekologicznej oraz społecznej. Ten fakt stał się podstawą badań tej interesującej podgrupy, wyodrębnionej z całej zbiorowości badanych przedsiębiorstw. Badanie przeprowadzono wielowątkowo. W pierwszej kolejności scharakteryzowano przedsiębiorstwa, które wskazały na pomiar celów nie tylko w płaszczyźnie finansowej, ale też ekologicznej lub społecznej. Wychodząc z założenia, że strategię zrównoważonego rozwoju realizują przedsiębiorstwa formułujące cele i mierniki równocześnie we wszystkich trzech płaszczyznach, w drugim etapie wyodrębniono istotną z punktu widzenia tych założeń podgrupę badawczą i podano ją wielowątkowej analizie. Wyniki przeprowadzonych analiz prezentowane są $\mathrm{w}$ dwóch wariantach, a więc $\mathrm{w}$ odniesieniu do ogółu przedsiębiorstw w Polsce oraz na tle badanej grupy przedsiębiorstw.

\footnotetext{
* Dr hab. prof. US, Uniwersytet Szczeciński.

** Dr, Uniwersytet Szczeciński.
} 


\section{TWORZENIE TRWAŁEJ WARTOŚCI Z UWZGLĘDNIENIEM EFEKTÓW EKOLOGICZNYCH I SPOŁECZNYCH}

W teorii funkcjonują dwie konkurencyjne teorie wartości dla właścicieli i wartości dla wszystkich interesariuszy. Pierwsza koncepcja, określona przez A. Rappaporta jako Shareholder Value Approach, oznacza ukierunkowanie zarządzania firmą i wybór strategii działania na podstawie kryterium wartości tworzonej dla akcjonariuszy ${ }^{1}$. Głównym celem jest więc maksymalizacja wartości dla akcjonariuszy. Interesy innych grup stanowią środek dla osiągnięcia tak sformułowanego celu. Zadaniem menedżerów jest, w wypadku spółek publicznych, maksymalizacja dochodów akcjonariuszy tytułu wzrostu kursu akcji, dywidendy i praw własności z posiadania akcji.

W odróżnieniu od koncepcji Shareholder Value druga koncepcja Stakeholder Value wywodzi się z modelu „koalicji” R. M. Cyerta i J. G. Marcha². Zgodnie $\mathrm{z}$ tą koncepcją celem przedsiębiorstwa i jednocześnie środkiem jego realizacji są - uwzględnione w jednakowym stopniu - interesy jego partnerów. Przy tak sformułowanym celu, głównym zadaniem kierownictwa przedsiębiorstwa jest więc osiagnięcie pożądanej wielkości zysku, która powinna zapewnić bieżące i przyszłe inwestycje oraz przeżycie firmie.

Obie koncepcje mają swoich zwolenników i przeciwników. Od końca lat dziewięćdziesiątych dwudziestego wieku za wiodąca przyjmuje się teorię wartości dla akcjonariuszy. Obecnie jednak, wobec zwiększającej się wrażliwości społeczeństwa, inwestorów i klientów dla społecznych konformistycznych zachowań przedsiębiorstwa, staje się ona przedmiotem krytyki ${ }^{3}$. Przedsiębiorstwo jako wytwórca dóbr i usług, pracodawca i partner w procesach gospodarczych jest głównym twórcą dobrobytu. W związku z tym zasadniczym celem pozostaje długoterminowe wypełnianie oczekiwań właścicieli odnośnie poziomu rentowności. $\mathrm{Z}$ tym jednak, że silniej akcentowane są pozostałe długoterminowe czynniki decydujące o przetrwaniu i rozwoju przedsiębiorstw. Pracownicy odpowiednio wykwalifikowani są często jedynym źródłem przewagi konkurencyjnej. O długoterminowym trwaniu decydują więc działania w sferze społecznej, a w tym sprawiedliwy podział wytworzonej wartości oraz działania w zakresie ekologii. Trzy wymienione grupy celów zgodne z podstawowymi kompetencjami przedsiębiorstwa tworzą bazę strategicznej przewagi konkurencyjnej i są decydujące dla zapewnienia długoterminowej egzystencji każdej organizacji (rys. 1$)^{4}$.

\footnotetext{
${ }^{1}$ A. R a pap port, Sharoholder Value. Wertsteigerung als Massstab für die Unternehmensführung. Schäffer-Poeschel Verlag, Stuttgart 1995, s. 1-15.

${ }^{2}$ R. M. Cyert, J. G. March, A Behavioral Theory of the Firm, Englewoog Cliffs, New York 1963, s. 1-16.

3 T. Reichmann M. Kiß1er, Sustainability - controlling, „Controlling” 2010, nr 2, s. $104-106$.

${ }^{4}$ M. E. Porter, M. R. Kra me r, Corporate Social Responsibility, „Harvard Business Manager" 2007, Vol. 85, s. 25, [za:] T. M. F i s ch e r, A. S a w c z y n, B. B r a u c h, Nachhaltigkeit und
} 


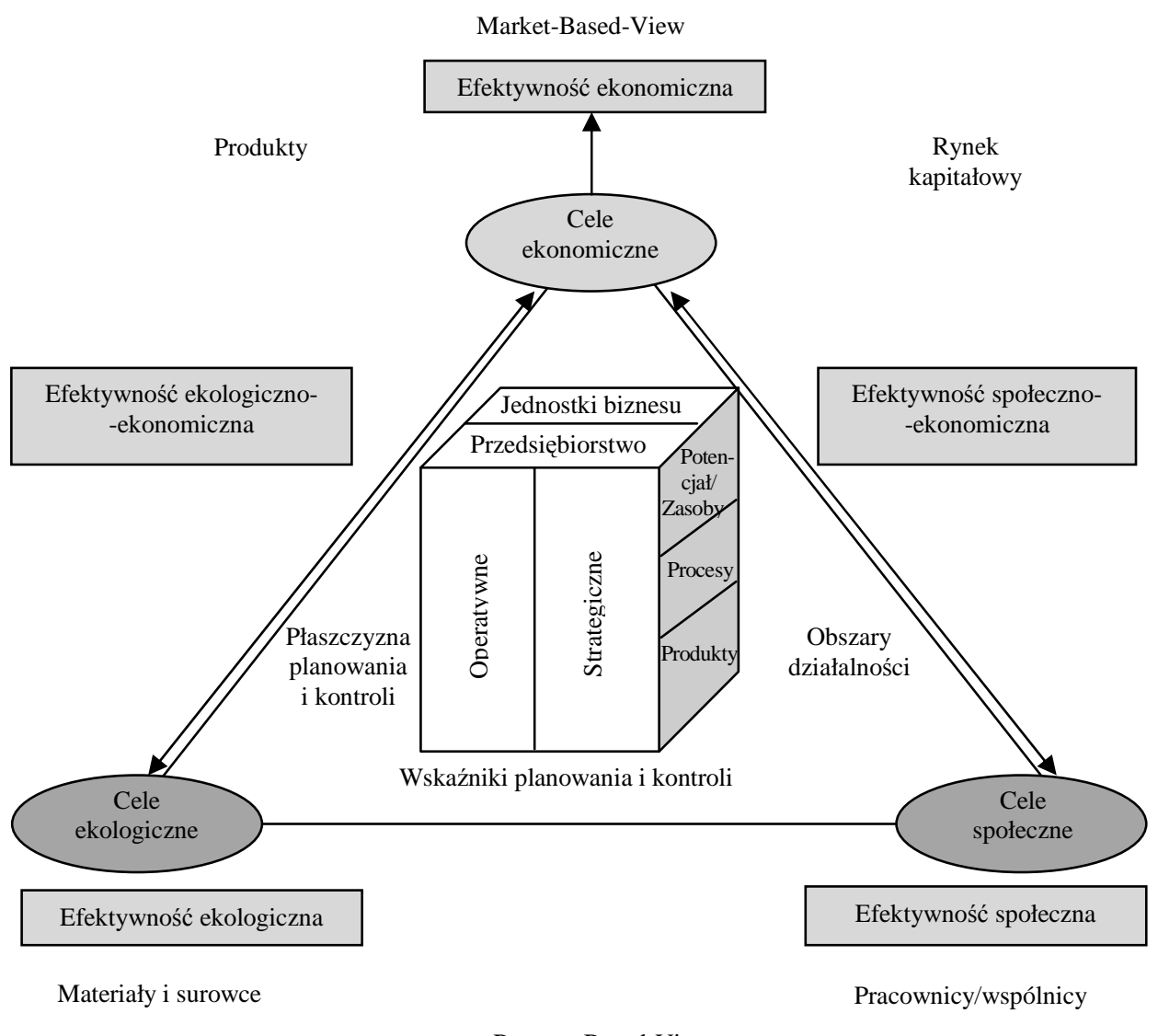

Resorce-Based-View

Rys. 1. Trójkąt zrównoważonego rozwoju przedsiębiorstwa

Źródło: opracowanie własne na podstawie T. M. Fischer, A. Sawczyn, B. Brauch, Nachhaltigkeit und Sustainability Accounting, [w:] F. W a 11, R.W. S c h rö d e r, Controlling zwischen Shareholder Value und Stakeholder Value. Neue Anforderungen, Konzepte und Instrumente, Oldenbourg Verlag, München 2009 s. 264 oraz T. Reichmann M. Kißler, Sustainability controlling, „Controlling” 2010, nr 2, s. 104-106.

W koncepcji zrównoważonego rozwoju przedsiębiorstwa łączy się elementy dwóch przeciwstawnych koncepcji wartości. Rozwój ekonomiczny, powiązany jest $\mathrm{z}$ rozwojem ekologicznym i społecznym. Powstały w ten sposób system celów przedsiębiorstwa jest wynikiem wzajemnej koordynacji celów ekono-

Sustainability Accounting, [w:] F. W all, R. W. S chröder, Controlling zwischen Shareholder Value und Stakeholder Value. Neue Anforderungen, Konzepte und Instrumente, Oldenbourg Verlag, München 2009, s. 263. 
micznych, a przede wszystkim właścicieli kapitałów oraz celów pozaekonomicznych, czyli celów pozostałych interesariuszy oraz występujących możliwości i ograniczeń. System celów obecnie charakteryzuje się wielkowymiarowością, z dającymi się wyróżnić częściowo zidentyfikowanymi zależnościami między konkurencyjnymi, komplementarnymi celami. Zgodnie z koncepcją tzw. celu niejednorodnego ścieżka rozwoju przedsiębiorstwa określona jest przez wiązkę celów, w której hierarchicznie nadrzędny jest strategiczny cel główny ${ }^{5}$. Zasadniczym lub też ostatecznym celem działalności przedsiębiorstwa, wyznaczającym kierunek jego działania, jest maksymalizacja wartości dla akcjonariuszy. Utrzymanie znaczenia wartości dla akcjonariuszy uzasadnione jest faktem, że właśnie tak określony cel jest wspólną miarą dla wszystkich płaszczyzn. Nie naraża on automatycznie przedsiębiorstwa na zachłanność i nieodpowiedzialne zachowanie, jest klarowny i jednoznaczny oraz najlepiej przystaje do globalnych rynków finansowych, gdzie ma miejsce przepływ kapitału do przedsięwzięć o najwyższych stopach zwrotu ${ }^{6}$.

\section{ZAŁOŻENIA METODYCZNE}

W identyfikacji przedsiębiorstw odpowiedzialnych społecznie wykorzystano wyniki badań nad pomiarem dokonań przeprowadzone przez Wydział Nauk Ekonomicznych i Zarządzania Uniwersytetu Szczecińskiego na podstawie decyzji $\mathrm{nr}$ 4366/B/H03/2011/40 w połowie 2012 roku w ramach pierwszego etapu projektu badawczego „Kluczowe indykatory osiągnięć w zarządzaniu wynikami przedsiębiorstwa". Celem tego etapu badania była diagnoza systemu pomiaru dokonań $\mathrm{w}$ przedsiębiorstwach polskich. Badanie ilościowe przeprowadzono techniką CATI. Próba do badania została dobrana w sposób nieproporcjonalny z bazy REGON. Badana populacja obejmowała przedsiębiorstwa małe, średnie i duże sektora przedsiębiorstw niefinansowych. Rozkład próby wynosił:

$\mathrm{n}=100$ przedsiębiorstw małych (zatrudnienie 10-49 osób),

$\mathrm{n}=100$ przedsiębiorstw średnich (zatrudnienie 50-249 osób),

$\mathrm{n}=100$ przedsiębiorstw dużych (zatrudnienie powyżej 250 osób).

W celu zapewnienia reprezentatywności przeprowadzonego badania opracowane zostały wagi analityczne, pozwalające odnieść wyniki przeprowadzonego badania, nie tylko do badanej grupy podmiotów, ale do ogółu polskich przedsiębiorstw. Dobrana próba była reprezentatywna ze względu na sekcję PKD

${ }^{5}$ K. J an as z, W. J an as z, K. Kozi oł, K. S z opik, Zarzqdzanie strategiczne. Koncepcje. Metody. Strategie, Difin, Warszawa 2008, s. 67-69; A. S t a b r yła, Podstawy zarzadzania firma: modele, metody, praktyka, PWN, Kraków-Kluczbork 2001, s. 13-21.

${ }^{6}$ Ch. Laszlo, Firma zrównoważonego rozwoju. Jak wypracować trwata wartość z uwzględnieniem efektów społecznych i ekologicznych, Wydawnictwo Studio Emka, Warszawa 2008, s. 66-67. 
w obrębie każdej z klas wielkości firm. Na potrzeby badania wyodrębniono następujące sekcje PKD: przetwórstwo przemysłowe (B, C, D, E) / budownictwo (F) / handel i naprawa $(\mathrm{G})$ / transport i gospodarka magazynowa $(\mathrm{H})$ / usługi I (I, J) / usługi II (L, M, N).

\section{WYNIKI PRZEPROWADZONEGO BADANIA UWZGLĘDNIAJĄCE ODRĘBNIE CELE I WSKAŹNIKI W PŁASZCZYŹNIE EKOLOGICZNEJ I SPOŁECZNEJ}

Uzyskane wyniki badania ankietowego pozwoliły ustalić, że znaczna liczba analizowanych przedsiębiorstw w rożnym stopniu uwzględnia w pomiarze dokonania z trzech wybranych płaszczyzn (tab. 1).

Płaszczyzny oceny niefinansowej i ich wagi

\begin{tabular}{|l|c|}
\hline \multicolumn{1}{|c|}{ Płaszczyzna } & Procent wskazań \\
\hline \hline Finansowa & 100,0 \\
\hline Ekologiczna & 21,2 \\
\hline Społeczna & 14,1 \\
\hline
\end{tabular}

Źródło: opracowanie własne.

Opisując grupę przedsiębiorstw, które wykazały płaszczyznę ochrony środowiska jako istotną w pomiarze dokonań, należy zauważyć, że jest to grupa niejednorodna i nie zawsze cel w postaci zrównoważonego rozwoju jest motywatorem do uwzględniania tej płaszczyzny w pomiarze osiagnięć. Charakterystykę tych przedsiębiorstw z punktu widzenia ich wielkości przedstawiono w tab. 2 .

Tabela 2

Struktura przedsiębiorstw mierzących dokonania w płaszczyźnie ekologicznej z punktu widzenia ich wielkości

\begin{tabular}{|l|c|c|}
\hline \multicolumn{1}{|c|}{ Treść } & $\begin{array}{c}\text { Udział w ogólnej ilości } \\
\text { przedsiębiorstw w Polsce }\end{array}$ & $\begin{array}{c}\text { Udział w badanej grupie } \\
\text { małych/średnich/dużych }\end{array}$ \\
\hline \hline Małe & $11,8 \%$ & $14,0 \%$ \\
\hline Średnie & $8,6 \%$ & $27,0 \%$ \\
\hline Duże & $0,8 \%$ & $33,0 \%$ \\
\hline
\end{tabular}

Źródło: jak do tab. 1.

Jak wynika z przedstawionych danych, struktura przedsiębiorstw w Polsce istotnie determinuje strukturę przedsiębiorstw uwzględniających cele ekologicz- 
ne z punktu widzenia ich wielkości. W takim ujęciu najwięcej małych przedsiębiorstw zainteresowanych jest problematyką ekologiczną. Inny ogląd sytuacji uzyskuje się na podstawie drugiego z przedstawionych kryteriów klasyfikacji. Na każde 100 badanych przedsiębiorstw, 33 to przedsiębiorstwa duże, 27 średnie i tylko 14 to przedsiębiorstwa małe. Przedsiębiorstwa małe prowadzą działalność mieszczącą się w sekcji $\mathrm{G}$ - handel i naprawa, F - budownictwo, a także usługi w sekcjach: L, M, N. Wśród przedsiębiorstw średnich i dużych dominują przedsiębiorstwa przemysłowe. Nielicznie reprezentowane są inne podmioty z sekcji: handel i naprawa (sekcja G) oraz usługi (sekcje L, M, N).

$\mathrm{W}$ grupie przedsiębiorstw dużych znalazły się, obok przedsiębiorstw z kapitałem polskim, tak jak to miało miejsce $w$ poprzednich dwóch grupach, także i przedsiębiorstwa z kapitałem zagranicznym.

Podsumowując należy zauważyć, że cele w zakresie ochrony środowiska formułowane są głównie przez przedsiębiorstwa przemysłowe, duże i średnie. Są to podmioty rentowne o długim okresie funkcjonowania (większość podmiotów funkcjonuje powyżej 10 lat), raczej zadowolone $\mathrm{z}$ istniejącego systemu pomiaru dokonań i bardzo szeroko wykorzystujące go w praktyce.

Działalność społeczną zadeklarowało $14,1 \%$ przedsiębiorstw polskich, a więc znacznie mniej niż w płaszczyźnie ekologicznej. Ich strukturę z punktu widzenia wielkości, również w dwóch ujęciach, zawiera tab. 3.

Tabela 3

Struktura przedsiębiorstw mierzących dokonania w płaszczyźnie społecznej z punktu widzenia ich wielkości

\begin{tabular}{|l|c|c|}
\hline \multicolumn{1}{|c|}{ Treść } & $\begin{array}{c}\text { Udział w ogólnej ilości } \\
\text { przedsiębiorstw } \\
\text { w Polsce }\end{array}$ & $\begin{array}{c}\text { Udział w badanej grupie } \\
\text { małych/średnich/dużych }\end{array}$ \\
\hline \hline Małe & $5,1 \%$ & $6,0 \%$ \\
\hline Średnie & $8,7 \%$ & $18,0 \%$ \\
\hline Duże & $0,3 \%$ & $11,0 \%$ \\
\hline
\end{tabular}

Źródło: jak do tab. 1.

Niezależnie od przyjętego podejścia do oceny wyraźnie widać, że cele społeczne i mierniki ich oceny dominują w przedsiębiorstwach średnich. Ma to swoje uzasadnienie logiczne. Przedsiębiorstwa małe nie mają zazwyczaj takiego potencjału, aby realizować działania o charakterze społecznym. Przedsiębiorstwa duże natomiast prowadzą działalność na większą skalę, często na większym obszarze. Fakt ten decyduje o tym, że prowadząc działalność społeczną, nie mogą skupić się na potrzebach wielu społeczności lokalnych. 
Charakteryzując grupę przedsiębiorstw aktywnych w obszarze działań społecznych można zauważyć, że podobnie jak w poprzedniej płaszczyźnie wśród przedsiębiorstw małych są to podmioty prowadzące działalność mieszczącą się w sekcji: $\mathrm{G}$ - handel i naprawa, F - budownictwo, a także usługi w sekcjach L, M, N. Wśród przedsiębiorstw średnich i dużych dominują przedsiębiorstwa przemysłowe. Nielicznie reprezentowane są inne podmioty $\mathrm{z}$ sekcji handel i naprawa (sekcja G) oraz usługi (sekcje: L, M, N). W grupie podmiotów dużych znajdują się zarówno przedsiębiorstwa z kapitałem polskim, jak i kapitałem zagranicznym.

To, co odróżnia duże przedsiębiorstwa od pozostałych, to wysoka świadomość działania. Wszystkie podmioty posiadają strategię działania opisaną wskaźnikami. Stanowią one w większości uporządkowany system wskaźników finansowych i niefinansowych o szerokim spektrum zastosowania.

Podsumowując analizę przedsiębiorstw działających prospołecznie, można wyróżnić dwie grupy podmiotów. Pierwsza z nich jest zbiorem przedsiębiorstw o ugruntowanej pozycji na rynku i dobrej kondycji finansowej, dzięki czemu mogą one realizować działalność społeczną. Są to podmioty w większości małe i średnie. Działalność społeczna nie zawsze wynika u nich ze strategii działania, ale $\mathrm{z}$ innych przesłanek.

Druga, bardzo jednorodna grupa podmiotów, to przedsiębiorstwa o określonej strategii działania opisanej wskaźnikami finansowymi i niefinansowymi tworzącymi system. Są to podmioty średnie i duże, rentowne i o ugruntowanej pozycji na rynku. Działalność społeczna jest więc elementem strategii działania tych podmiotów.

\section{SYLWETKA PRZEDSIĘBIORSTWA SPOŁECZNIE ODPOWIEDZIALNEGO}

Oddzielanie celów ekonomicznych od celów społecznych i ekologicznych, stosowanie odrębnej terminologii, odrębnych mierników i narzędzi do ich raportowania jest powodem powstania trzech różnych, trudnych do powiązania ze sobą zestawów wskaźników ${ }^{7}$. R. S. Kaplan i D. P. Norton uznali, że skuteczna realizacja strategii jest możliwa wówczas, gdy przedsiębiorstwo zdefiniuje cele i określi sposoby ich pomiaru na czterech płaszczyznach, tj. finansowej, klientów, procesów wewnętrznych, uczenia się i rozwoju ${ }^{8}$. Podstawowym celem pomiaru dokonań jest więc zdolność do mierzenia wyników w taki sposób, by zmusiły członków organizacji do działania zgodnego ze strategią ${ }^{9}$. W klasycznej

\footnotetext{
${ }^{7}$ Ch. Laszlo, op. cit., s. 22.

${ }^{8}$ R. S. Kapla n, D. P. Norton, Strategiczna karta wyników. Jak przetożyć strategię na działanie, Arthur Andersen, Wydawnictwo Naukowe PWN, Warszawa 2001.

9 R. N. Anthony, V. Govindarajan, Management control system, R.R. Donnelley\&Sons, Boston 2000, s. 456, [za:] J. M i c h a la k, Pomiar dokonań od wyniku finansowego do Balanced Scorecard, Difin, Warszawa 2008, s. 51.
} 
postaci strategiczna karta wyników nie uwzględnia celów socjalnych i ekologicznych istotnych w rozwoju zrównoważonym. Pierwszy mankament proponuje się wyeliminować przez przekształcenie strategicznej karty osiagnięć w zrównoważoną strategiczną kartą osiagnnięć (Sustainability Balanced Scorecard). W tym wypadku powstaje problem dodatkowego uwzględnienia celów socjalnych i ekologicznych i ich wskaźników. W literaturze proponuje się trzy rozwiązania w tym zakresie, a więc:

a) ujęcie ich we wcześniejszych płaszczyznach,

b) wprowadzenie nowych płaszczyzn,

c) zmianę treści i pojęcia konwencjonalnych płaszczyzn ${ }^{10}$.

Kompleksowość podejścia do realizacji strategii zrównoważonego rozwoju wymaga więc takich samych rozwiązań w zakresie sposobów ich oceny. Rzeczywista realizacja tej koncepcji wymaga równoczesnego zdefiniowania celów ekonomicznych, społecznych oraz ekologicznych i określenia sposobów ich pomiaru.

Założono, że jeżeli przedsiębiorstwa mają strategię i jest ona opisana zarówno wskaźnikami finansowymi, jak i ekologicznymi oraz społecznymi, to one właśnie realizują strategię zrównoważonego rozwoju. Jest to podejście z pewnością uproszczone. Samo zdefiniowanie celów w trzech płaszczyznach nie oznacza, że są one ze sobą powiązane związkami przyczynowo-skutkowymi. Jednocześnie jest też podejściem odmiennym od prezentowanego $\mathrm{w}$ raporcie „Odpowiedzialny biznes w Polsce 2012”, gdzie przedmiotem prezentacji pozostają dobre praktyki ${ }^{11}$.

Przedsiębiorstwa społecznie odpowiedzialne, których działalność wynika ze strategii, to jedynie 2,5\% ogółu przedsiębiorstw w Polsce. Na rys. 2 przedstawiono ich strukturę z punktu widzenia wielkości określonej liczbą zatrudnionych.

Jak wynika $\mathrm{z}$ rys. 2 , w tej grupie podmiotów dominują przedsiębiorstwa średnie. Stanowią one 1,4\% ogółu przedsiębiorstw. W tab. 4 zawarto charakterystykę profilu działania wybranych przedsiębiorstw.

Przedstawione zestawienie pokazuje, że przedsiębiorstwa zrównoważonego rozwoju to głównie przedsiębiorstwa przemysłowe (stanowią one 1,3\% wszystkich przedsiębiorstw w Polsce i jednocześnie ponad połowę wszystkich przedsiębiorstw społecznie odpowiedzialnych) oraz usługowe z sekcji L, M, N (1\%). Pozostałe sekcje są reprezentowane $\mathrm{w}$ niewielkim stopniu. Jest to odmienna struktura od ogółu badanych podmiotów. Co prawda, przedsiębiorstwa przemysłowe dominują również wśród ogółu badanych podmiotów, jednakże stanowią one $33,9 \%$ ogółu, a więc niewiele ponad jedną trzecią. Podobna sytuacja ma miejsce w usługach II, w sekcjach: L, M, N.

${ }^{10}$ T. M. F is che r, R. Hu be r, A. S a w c z y n, Nachhaltige Unternehmensführung als Herausforderung für das Controlling, „Controlling” 2010, nr 4/5.

${ }^{11} \mathrm{http}: / / \mathrm{www} . c s r i n f o . o r g /$ images/stories/Publikacje_2013/raport\%20odpowiedzialny\%20bizn es $\% 20$ w\%20polsce $\% 202012 \% 20$ dobre\%20praktyki.pdf. 


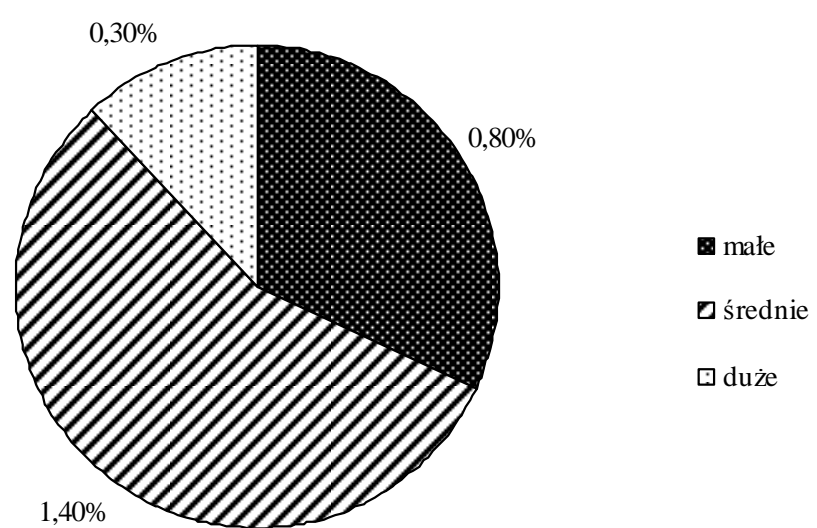

Rys. 2. Procentowy udział przedsiębiorstw zrównoważonego rozwoju według wielkości zatrudnienia pośród wszystkich przedsiębiorstw w Polsce w 2012 r.

Źródło: opracowanie własne.

Tabela 4

Profil działania przedsiębiorstwa zrównoważonego rozwoju

\begin{tabular}{|l|c|c|}
\hline \multicolumn{1}{|c|}{ Treść } & $\begin{array}{c}\text { Udział w ogólnej liczbie } \\
\text { przedsiębiorstw w Polsce }\end{array}$ & $\begin{array}{c}\text { Udział w ogólnej liczbie } \\
\text { badanych przedsiębiorstw }\end{array}$ \\
\hline \hline Przemysł Sekcje - B, C, D, E & $1,3 \%$ & $33,9 \%$ \\
\hline Budownictwo Sekcja - F & $0,1 \%$ & $14,8 \%$ \\
\hline Handel i naprawa Sekcja - G & $0,1 \%$ & $28,1 \%$ \\
\hline $\begin{array}{l}\text { Transport i gospodarka magazynowa } \\
\text { Sekcja - H }\end{array}$ & $0,0 \%$ & $4,8 \%$ \\
\hline Usługi I Sekcje - I, J & $0,0 \%$ & $7,1 \%$ \\
\hline Usługi II Sekcje - L, M, N & $1,0 \%$ & $11,3 \%$ \\
\hline RAZEM & $2,5 \%$ & $100 \%$ \\
\hline
\end{tabular}

Źródło: jak do tab. 1.

Charakteryzując podmioty kierujące się strategią zrównoważonego rozwoju należy zauważyć, że są to jednostki gospodarcze głównie z kapitałem polskim, prywatnym. Stanowią one 2,2\% ogółu przedsiębiorstw.

Podmioty kierujące się strategią zrównoważonego rozwoju funkcjonują średnio minimum 6 lat na rynku. Około 1,6\% z nich prowadzi swoją działalność na rynku od ponad 10 lat.

Prezentacja sylwetki przedsiębiorstwa zrównoważonego rozwoju wiąże się $\mathrm{z}$ opisaniem wskaźników $\mathrm{w}$ trzech przedstawionych powyżej płaszczyznach: finansowej, ochrony środowiska i działalności społecznej. 
Wskaźniki stosowane w płaszczyźnie finansowej przez przedsiębiorstwa o zrównoważonym rozwoju i ogół przedsiębiorstw zaprezentowano na rys. 3 .

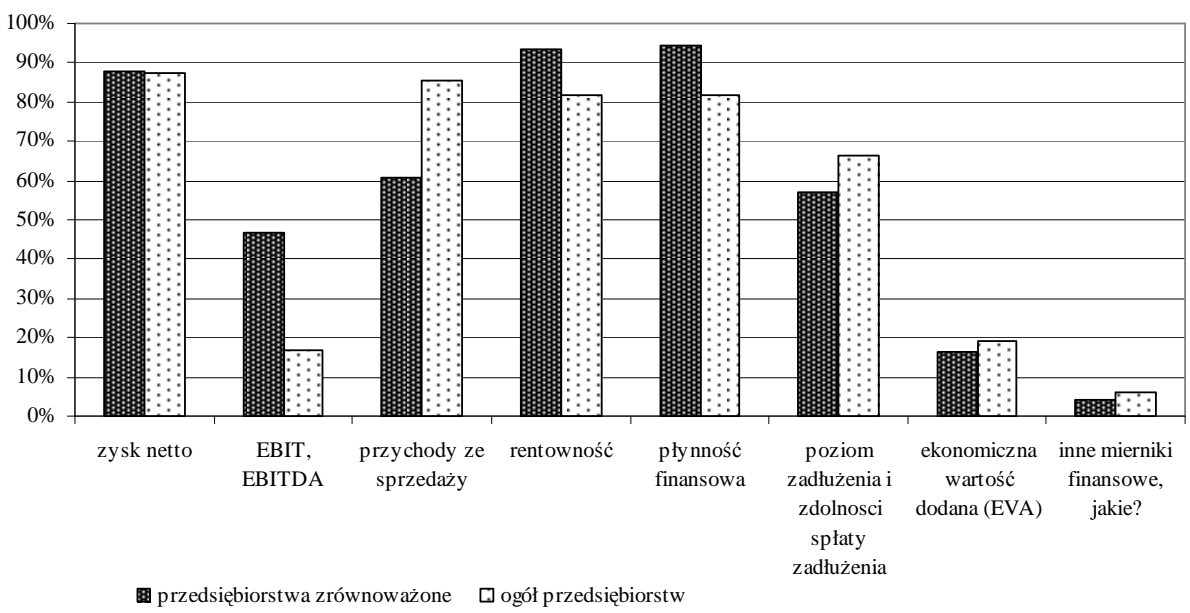

Rys. 3. Wskaźniki stosowane w płaszczyźnie finansowej

Źródło: jak do rys. 2.

Jak wynika z rys. 3, wskaźniki stosowane w płaszczyźnie finansowej wśród zidentyfikowanej grupy przedsiębiorstw zrównoważonego rozwoju w porównaniu do ogółu, różnią się dosyć istotnie. Przedsiębiorstwa zrównoważone kładą większy nacisk na mierniki oparte na zysku. Dla przykładu zastosowanie EBIT lub EBITDA docenia co szóste przedsiębiorstwo, podczas gdy wśród podmiotów o strategii zrównoważonego rozwoju prawie połowa z nich. Podobne dysproporcje, choć o mniejszej amplitudzie są zauważalne przy wskaźnikach rentowności.

Jednocześnie przedsiębiorstwa zrównoważonego rozwoju kładą mniejszy nacisk na przychody ze sprzedaży. Może to się wiązać z tym, że są to przedsiębiorstwa w fazie dojrzałej, gdzie liczy się utrzymanie wysokich marży, a zwiększenie udziałów w rynku jest celem drugorzędnym lub pochodnym.

Jeżeli chodzi o ważność poszczególnych wskaźników, nie ma istotnych różnic pomiędzy badaną grupa, a ogółem. Najbardziej istotne wskaźniki to niezmiennie: zysk netto, przychody ze sprzedaży, rentowność, płynność finansowa.

Wśród wskaźników dotyczących ekologii, stosowane są wskaźniki charakterystyczne dla rodzaju prowadzonej działalności. Są często powiązane z wymogami formalno-prawnymi prowadzonej działalności. Respondenci wymienili następujące obszary, w których identyfikują wskaźniki: normy ISO 9001, 14001, 18001; wskaźniki emisji zanieczyszczeń; opłaty i kary za korzystanie ze środowiska, wyeliminowanie hałasu; wywóz odpadów przez firmy, które zajmują się 
utylizują; współczynnik złomowanego materiału w stosunku do zużytego; współczynnik segregacji odpadów; wielkość odpadów możliwych do recyklingu; pomiary zrzutu ścieków; stopień zużycia wody w naszych produktach; program zero odpadów; system doradztwa ekologicznego; wskaźnik ilości odpadów niebezpiecznych, toksycznych; wskaźnik zużycia mediów (woda, gaz); program ochrony przyrody; zmiana ogrzewania węglowego na gazowe; akcje dla klientów; projekty godziny dla ziemi; zbiórka baterii, opakowań papierowych oraz folii; ilość wydanych mandatów za zaśmiecanie; stosowanie środków, maszyn i urządzeń spod znaku eko; wydajność grzewcza w zimie.

Działalność społeczna przedsiębiorstw ma często formę projektów i akcji zarówno o charakterze jednorazowym, jak i ciagłym. Realizowana jest niejednokrotnie w celu reklamy, bądź utrwalenia pozytywnego wizerunku firmy wśród społeczności lokalnej. Respondenci wymienili następujące obszary, w których identyfikują wskaźniki: rehabilitacja zawodowa; darowizny; sponsoring imprez sportowych i kulturalno-oświatowych w mieście; wsparcie dla drużyn piłkarskich, domów dziecka, przedszkoli, szkół i szpitali, fundacji; liczba inwestycji społecznych; zadowolenie ze współpracy z partnerami mierzone za pomocą otrzymanych nagród; zadowolenie osób, które korzystają z pomocy społecznej; zadowolenie mieszkańców; telefony mówiące o dobrej działalności; badania opinii publicznej; ilość uczestników biorących udział w akcja charytatywnych; zatrudnianie osób z domu dziecka.

Scharakteryzowany system wskaźników w $92 \%$ przypadków jest opracowaniem własnym przedsiębiorstwa, zaczerpniętym z teorii. W 76\% przypadków system ten jest powiązany z systemem motywacyjnym, a w 100\% wskaźniki są zgodne z celami strategicznymi i służą do pomiaru i oceny dokonań działalności przedsiębiorstwa oraz do kontroli prowadzonej działalności bieżącej

\section{ZAKOŃCZENIE}

Prowadzone badania, zarówno w świecie, jak i w Polsce, potwierdzają rosnącą liczbę przedsiębiorstw deklarujących wdrażanie CSR. Coraz częściej jest to powiązane $\mathrm{z}$,twardymi” działaniami jak mierzenie wpływu i raportowanie. W roku 2012 przeprowadzone badania dotyczyły: publikacji danych niefinansowych przez największe polskie spółki i jej form, związku pomiędzy innowacyjnością przedsiębiorstwa i jego odpowiedzialnością, barier współpracy międzysektorowej, czy też wpływu udziału kobiet w zarząadach spółek na wyniki finansowe ${ }^{12}$.

${ }^{12}$ R. Putkow ska, M. Grzybek, CSR $w$ badaniach $w$ roku 2012, [w:] Raport odpowiedzialny biznes $w$ Polsce $w$ roku 2012. Dobre praktyki;

http://www.csrinfo.org/images/stories/Publikacje_2013/raport\%20odpowiedzialny\%20biznes\%20 w\%20polsce\%202012\%20dobre\%20praktyki.pdf. 
Zaprezentowane podejście ostatecznie dotyczy realizacji strategii zrównoważonego rozwoju przez przedsiębiorstwa polskie. Przeprowadzone badania pozwoliły wyodrębnić dwie grupy podmiotów.

- Pierwsza, liczniejsza, to przedsiębiorstwa, które oprócz celów finansowych uwzględniają też wybrane cele z grupy ekologicznej lub społecznej. Działalność społeczna czy ekologiczna nie zawsze więc wynika u nich ze strategii działania, ale z innych przesłanek.

- Druga, znacznie mniejsza, to przedstawione 2,5\% przedsiębiorstw społecznie odpowiedzialnych w świetle przedstawionych kryteriów. Są to z reguły przedsiębiorstwa średnie, przemysłowe lub usługowe II (sekcje: B, C, D, E, L, $\mathrm{M}, \mathrm{N}$ ) funkcjonujące od minimum 6 lat z kapitałem polskim, prywatnym.

Analizując płaszczyznę finansową, przedsiębiorstwa zrównoważone kładą większy nacisk na wskaźniki oparte na zysku, a mniejszy na przychody ze sprzedaży. Może to się wiązać z tym, że są to przedsiębiorstwa w fazie dojrzałej, gdzie liczy się utrzymanie wysokich marży, a zwiększenie udziałów w rynku jest celem drugorzędnym lub pochodnym.

Wśród wskaźników dotyczących ochrony środowiska, stosowane są mierniki charakterystyczne dla rodzaju prowadzonej działalności. Są często powiązane z wymogami formalno-prawnymi prowadzonej działalności. Najwięcej odpowiedzi dotyczyło obciążenia środowiska emisją szkodliwych substancji do atmosfery i opłatami i karami za korzystanie ze środowiska.

Działalność społeczna przedsiębiorstw ma często formę projektów i akcji zarówno o charakterze jednorazowym, jak i ciagłym. Realizowana jest często w celu reklamy, bądź utrwalenia pozytywnego wizerunku firmy wśród społeczności lokalnej.

\section{BIBLIOGRAFIA}

Anthony R. N., Govindarajan V., Management control system, R.R. Donnelley\&Sons, Boston 2000, [za:] J. Michalak, Pomiar dokonań od wyniku finansowego do Balanced Scorecard, Difin, Warszawa 2008.

Cyert R. M., March J. G., A Behavioral Theory of the Firm, Englewoog Cliffs, New York 1963.

F i s che r T. M., Hu be r R., S a w c z y n A., Nachhaltige Unternehmensführung als Herausforderung für das Controlling, „Controlling” 2010, $\mathrm{nr} 4 / 5$;

http://www.csrinfo.org/images/stories/Publikacje_2013/raport\%20odpowiedzialny\%20biznes $\% 20 w \% 20$ polsce\%202012\%20dobre\%20praktyki.pdf.

J a n a s z K., J a n a s z W., K o zi oł K., S z o p i k K., Zarzqdzanie strategiczne. Koncepcje. Metody. Strategie, Difin, Warszawa 2008.

K a pl a n R. S., N or to n D. P., Strategiczna karta wyników. Jak przetożyć strategię na działanie, Arthur Andersen, Wydawnictwo Naukowe PWN, Warszawa 2001.

L a s z lo Ch., Firma zrównoważonego rozwoju. Jak wypracować trwałq wartość z uwzględnieniem efektów społecznych i ekologicznych, Wydawnictwo Studio Emka, Warszawa 2008.

Porter M. E., Kramer M. R., Corporate Social Responsibility, „Harvard Business Manager” 2007, Vol. 85, s. 25, [za:] T. M. Fi s ch e r, A. S a w c z y n, B. B r a u c h, Nachhaltigkeit und 
Sustainability Accounting, [w:] F. W all, R. W. Schröder, Controlling zwischen Shareholder Value und Stakeholder Value. Neue Anforderungen, Konzepte und Instrumente, Oldenbourg Verlag, München 2009.

Putkowska R., Grzybek M., CSR $w$ badaniach $w$ roku 2012, [w:] Raport odpowiedzialny biznes $w$ Polsce $w$ roku 2012. Dobre praktyki;

http://www.csrinfo.org/images/stories/Publikacje_2013/raport\%20odpowiedzialny\%20biznes $\% 20$ w\%20polsce\%202012\%20dobre\%20praktyki.pdf.

$\mathrm{R}$ a p a p o r t A., Sharoholder Value. Wertsteigerung als Massstab für die Unternehmensführung. Schäffer-Poeschel Verlag, Stuttgart 1995.

Re i ch m a n T., K i ß l e r M., Sustainability - controlling, „Controlling” 2010, nr 2.

S t a b r yła A., Podstawy zarzqdzania firmq: modele, metody, praktyka, PWN, Kraków-Kluczbork 2001.

Wanda Skoczylas,

Andrzej Niemiec

\section{SOCIAL RESPONSIBLE ENTERPRISES IN A VIEW OF PERFORMANCE MEASUREMENT RESEARCH}

The aim of this article was to identify and describe social responsible enterprises in Poland. The basis of identification process was the assumption, that social responsible enterprises have strategy, that consist of targets an measures in three dimensions: financial, ecological and social. Translation the strategy into the targets and measures in following dimensions, is a necessary condition of sustainable growth strategy. The data source were survey results in non-financial enterprises in Poland, in a half 2012 year.

Key words: sustainable development, social responsible, performance measurement. 